The role of transnational networking for higher education academics

Wakefield, $\mathrm{K}$

http://hdl.handle.net/10026.1/8619

10.1080/07294360.2015.1024630

Higher Education Research \&amp; Development

Informa UK Limited

All content in PEARL is protected by copyright law. Author manuscripts are made available in accordance with publisher policies. Please cite only the published version using the details provided on the item record or document. In the absence of an open licence (e.g. Creative Commons), permissions for further reuse of content should be sought from the publisher or author. 


\section{The role of transnational networking for higher education academics}

Kelly Wakefield

Centre for Innovation and Leadership in Health Science, University of Southampton, Southampton, $U K$

Harriet Dismore

Southampton Education School, University of Southampton, Southampton, UK

Building 45/Room 1028

University of Southampton

Highfield Campus

Southampton

SO17 1BJ

Tel 02380598277

Email k.wakefield@soton.ac.uk

Provide short biographical notes on all contributors here if the journal requires them. 


\section{The role of transnational networking for higher education academics}

Amidst rapid socio-economic change, higher education academics across the world face major challenges to its organisation, finance and management. This paper discusses the role of transnational networking in higher education. Data from 40 interviews with geographically distributed academics engaged in learning and teaching transnational networks were analysed using a grounded methodological approach. The findings show that in an increasingly globalised higher education system, transnational networking goes beyond conference attendance to entail multiple combinations of offline and online activities. We do not think that current concepts of communities of practice or networks of practice accurately describe these phenomena. Instead, we suggest that these activities entail different and varying levels of tangibility, more accurately defined by us as transnational networks (TNN). Moreover, we argue that the term 'network' in this context facilitates the individualistic pursuit of a career increasingly essential in a pressurised higher education environment.

Keywords: higher education; networks; transnational

\section{Introduction}

Over the last four decades HE has experienced a radical expansion. In 2008 it was estimated that there were 150 million students in $\mathrm{HE}$ around the world, an increase from 68 million in 1991 (Bhandari \& Blumenthal, 2008). Furthermore, the struggle for some developing countries to keep up with the demand for university places has led to an increase in the numbers of students studying outside their home country (Maringe \& Foskett, 2010). These changes have, it is argued, put more pressure on the university structures and also on academics to cope with the sometimes conflicting teaching and research demands (Clegg, 2008).

These developments have led to transnational, perhaps even 'borderless' networks, that operate on and offline (Larsen, Axhausen \& Urry, 2006). Yet work on transnational academic mobility has focused primarily on medium to longer-term physical movement to and around other countries rather than remote networking (Kim, 2010; Jöns, 2011). Whilst earlier work has tended to concentrate on how networks are established and maintained, more recent research explores networks from the 
perspectives of groups or communities (McCormick, Carmichael, Fox \& Procter, 2010). Fewer studies however, have focused on how individuals engage in and experience networks and so this gap within the literature highlights the need to explore utility of networks from the perspective of the individual academic within the wider HE system.

Amidst complex relationships between learning and teaching, research and administration duties, higher education networks are an increasingly important area of study. Yet little information is available about how networks can negotiate the challenges of a modern higher education environment. This paper explores the role of transnational networks in HE by drawing on data from 40 interviews with academics engaged in learning and teaching networks. We argue that firstly, networking entails multiple combinations of offline and online activities that the concepts of Communities of Practice (CoP) and Networks of Practice (NoP) do not accurately describe. Instead these activities can vary in terms of tangibility that are more appropriately termed 'transnational networks'(TNN). Secondly, the 'networking' appears to mask individualistic pursuits influenced by an increasingly pressurised HE environment.

\section{Review of the literature}

Increasingly, discussions within higher education, particularly within geographies of higher education, are focussing on transnational academic mobility (see, for example, Jöns, 2007; 2011), international student mobility (see, for example, Waters, 2006a; 2006b) and international collaborations in higher education (see, for example, Donert et al, 2011). Despite this less is known about the online networking practices of academics (see, for example, Larson et al, 2006). Holloway and Jöns (2012) for example have brought together several discussions from the emerging geographies of education to aid our understanding of the many varied fields that 
contribute to this area. By bringing together literature on $\mathrm{CoP}$, NoP and the concept of transnationality within the wider narrative of higher education, this paper suggests a framework for engaging with learning and teaching networks.

\section{Higher Education}

Higher education in its current state as a global entity is a complex and multifaceted concept that has been debated widely in many areas of academic discourse (see, for example, Slaughter and Larry, 1997; Usher and Medow, 2010). The globalisation of higher education is often discussed alongside the internationalisation of higher education. A vast body of literature discusses the relationship, as well as differences and similarities between the two concepts (see, for example, Marginson and Van der Wende, 2006; Altbach and Knight, 2007). The terms are often confused (Altbach, 2004) or used synonymously and so it is important to stress that the two processes are related but in fact different (Knight, 2003). De Wit (2011) argues that many new terms emerging in the debate about the internationalisation of higher education are in fact a consequence of the impact of globalisation, overlapping and are intertwining (Scott, 2000). The globalisation of higher education cannot simply be seen as a higher form of internationalisation as it not only transcends national boundaries, it ignores them (Scott (2000). It can be argued that globalisation has profoundly influenced higher education by shaping it beyond the control of the university whereas internationalisation is the policy or programme that universities implement in response to these changes (Altbach et al,

The globalisation and internationalisation of higher education has often been seen through the lens of increasing student mobility (see, for example, David, Fung \& Han, 
2008; Teichler, 2012; King and Ruiz-Gelices, 2003) both short-term (Findlay et al, 2006) and long-term (Brooks and Waters, 2011). Yet more recently it has been considered via academic mobility (Tremblay, 2005) broadening out to include gender (Holloway, O’Hara \& Pimlott-Wilson, 2012), cultural contexts for research stays (Jöns, 2009; 2011) and ethnicity, including citing knowledge diasporas as vital transnational human capital (Yang \& Welch, 2012) as well as long-standing concerns of high-skilled (non)returnees (Hao \& Welch, 2012).

\section{Transnational spaces/networks}

Despite the rhetoric surrounding these two terms, this paper and the study it reports uses the concept transnational rather than global or international. This is intentionally to highlight the idea of 'between' or 'above' territorial boundaries, with emphasis on what is occurring in 'transnational space' (Kim, 2008) rather than interactions between or within academic's domicile or current national residences. Within the last decade emerging conversations on transnational networks have included global networks that link world cities (see, for example, Taylor, 2004; Flint and Taylor, 2007). Such conversations about the 'network society' 'have debated the relationship between information technologies and space. Castells' (1996) theory of the space of places and the space of flows has led to a change in how social space has been viewed. Historically, society's spatial form has been a space of places, for example, a world map showing political borders and nation states. However, the transnationalism of our globalised world transcends these places. For Castells our world is dominated by space of flows at the expense of the space of place (Flint and Taylor, 2007). Nevertheless, Sassen (1994) identified how global cities remain key economic sites within a globalised world. Both Sassen and Castells have reformulated their theories, seemingly 
compromising in understanding our world. We all work online sometimes but continue to work in places (Castells, 1996) whilst place maintains its importance yet local has a global span further recognising that localities are not only on concrete places but are also in digital networks spanning the globe (Sassen, 2002). Academic networking takes advantage of this networked society by using multiple personal and institutional connections to communicate information.

\section{Communities of Practice}

In order to situate academic networking within transnational space, the literature on $\mathrm{CoP}$ and NoP is also considered to enable a framing of both virtual and physical relationships. CoP are most commonly found within areas of business, organisational theory and knowledge management (whereas NoP, considered later, are more often discussed in the areas of information management and information technology). Previously, CoP have been described as local with 'local lore, shared stories, inside jokes, knowing laughter' (Amin \& Roberts, 2008, p. 354) and that they rely on 'local buzz' and meeting places (see, for example, Grabher \& Ibert, 2004; Bathelt, Malmberg \& Maskell, 2004). Although as Amin and Roberts (2004) noted, the original definition of CoP has become imprecise, CoP have long been considered 'stable' groups. Indeed, Cox (2007) discusses the vagueness of the term 'community' especially given that a CoP is not necessarily friendly or harmonious (Fox, 2000). We agree that the homogenisation of communities is unhelpful. There have been several problems associated with the defining and researching of $\mathrm{CoP}$ in particular. For example, it has been noted that most people who belong to a CoP may not think of themselves as members (Nickols, 2003) therefore making research of these groups difficult. Amin 
and Roberts (2008) also took issue with the increasingly homogenous use of the term CoP to encapsulate what they described as 'knowing in action'. They suggested that location, proximity and distance can be relationally rather than geographically determined. Complications arise when CoP exist in a variety of forms within different organisations so that there is a need to categorise them (Thompson, 2005) such as 'learning networks', 'knowledge communities', 'interest groups' and 'knowledge centres' (see, for example, Boland \& Tenkasi, 1995; Wenger, McDermott \& Snyder, 2002). Challenges also occur when participating in a CoP as negotiations need to be made in order to make sense of the $\mathrm{CoP}$ and participation within one. Wenger (1998) talked of 'modes of belonging' but changed this to 'modes of identification' (2000) that included imagination and alignment. Most importantly for this paper is engagement, the most immediate relation to practice, for example, engaging in activities, doing things, working alone or together and talking, in essence developing an identity of participation or non-participation. In other words, identity is a layering of participation by which our experience and it social interpretations inform each other, as we encounter our effects on the world and develop our relations with others, these layers build upon each other to produce identity (Wenger, 1998, p151).

\section{Networks of Practice}

NoP are closely connected to communities of practice CoP defined by Wenger (2000). Both describe a group of people who share a concern or passion for something they do and learn to do it better as they interact regularly (Wenger, 2006). Nevertheless, they differ in that NoP are characterised by their existence primarily through electronic communication (Brown \& Duguid, 2000To further distinguish 
between the two, networks and communities can also be differentiated in terms of outcomes. NoP share information but do not necessarily create new knowledge (Brown \& Duguid, 2000). Yet research into NoP has identified particular motives, including a sense of professional obligation and to be part of a community especially where participants are isolated (Faraj \& Wasko, 2001). Outcomes identified for participating in a CoP are different in that they have been known to include joint generation of knowledge (Ardichvili, Page \& Wentling, 2003), diffusion and adoption of new ideas (Swan, Newell \& Robertson. 1999) and reputation building (Stewart, 2003). How a $\mathrm{CoP}$ and NoP are defined can determine their impact. There has also been a blurring between the definitions as NoP have also been called Virtual Communities of Practice (VCoP) (Dubé, Bourhis \& Jacob, 2006) or Electronic Networks of Practice (ENoP) (Whelan, 2007).

\section{Networked individualism}

The literature on CoP challenges whether individualism or communityorientation are greater motivations for participation. For example, Putnam (2000) argues that people participate in community activities because they can derive some benefit from that involvement. There has also been some speculation about which orientations reap the most reward. Etzioni (1988) reported that when people are motivated by community-interest they are willing to work harder and are more likely to persevere in the face of adversity than people acting out of self-interest. The phrase 'networked individualism' (Cox, 2007; Rainie \& Wellman, 2012; Chua, 2013) has been used most recently to describe sparsely-knit networks that link individuals with little regard to space. Rainie and Wellman (2012) argue that this represents a new social operating 
system whereby people function more as networked individuals than in groups following a 'triple revolution' involving internet broadband, mobile connectivity and online social networking. This has led to looser and more fragmented networks operated by people who interact with numerous diverse others, doing several things more or less simultaneously. Academics too have experienced a shift from engaging in links which were sporadic, limited and international to dense, multiple and transnational networking.

Research with academics recognises the contribution of personal networks for supporting critical professional development, by equipping them with a diverse pool of knowledge and skills about teaching. In other words, what they learn can become embedded in their teaching practice (Dewsbury \& Naylor, 2002; Pataraia, Margaryan, Falconer \& Littlejohn, 2013). Moreover, as Wayne, Shore and Liden (1997) report, the benefits of sharing knowledge can mean supporting each other and ultimately leading to good citizenship. Others, such as Millen, Fontaine and Muller (2002) suggested that in order to fully understand the benefits of $\mathrm{CoP}$ such as improved communication, innovation and business project outcomes, values need to be categorised as tangible and intangible.

Yet, as Schlager and Fusco (2003) argue, what activates the positive outcomes of $\mathrm{CoP}$ or NoP are largely unresolved and practice itself has been at the centre of some concern. For example, the work of Lave and Wenger (1991) has been criticised for focusing primarily on newcomers to the group and not considering more experienced participants (Hager \& Hodkinson, 2009). Perhaps the most pertinent criticism of CoP literature is that it does not take into account the unequal access to learning at work (Hodkinson \& Hodkinson, 2005), which as Rainbird, Munro and Holly (2004) argue needs to be explicitly addressed as it characterises the employment relationship. 
Consequently, research methodologies have emerged to enable the study of the complexities of interaction within networks and communities. Activity theories (see for example, Engeström, 2001) focus on the structure of activities rather than on the individuals engaged in the activities. In contrast, organisational theories concern themselves with the ways in which individuals learn in organisational contexts and the ways in which organisations can be said to learn (Brown \& Duguid, 2000). ActorNetwork Theory (ANT) treats objects as part of the social and does not explain the 'whys' or the 'hows' of the network, rather just the form that it takes (Latour, 2005). Similarly, Social Network Analysis is designed to emphasise important features of social structures.

\section{'Academic tribes'}

Akin to identity, associated with Wenger's (1998) narrative regarding CoP, learning and meaning discussed earlier Becher's (1989) book on 'academic tribes' documents how academics tend to identify most strongly as members of particular disciplinary "tribes". The threefold major areas of academic work; teaching, research and service (see, for example, Buchbinder \& Newson, 1985) alongside later arguments of fourfold requirements; teaching, research, public service and institutional service (see, for example, Bowen \& Schuster, 1986) highlight a complexity whereby academics believe they 'fit' within the university and categorise themselves or are categorised by others. Increasing pressures on higher education have been reported with perceptions of time and the increasing tempo of university life restricting how one thinks about the future, particularly in terms of employability (Clegg, 2010). The costs of pressure in HE have also been discussed. Kolsaker (2008, p.514) argues that academics have been 
faced with a 'managerialist ideology', increasing pressure to behave in the interests of the organisation, implying less freedom and autonomy within a more structured and monitored environment. Indeed, Kligyte and Barrie (2014, p.165) refer to the managerialism in universities as 'the obstacle preventing the return to the collegiality fantasy'. They argue that in the face of this, academics are working harder on papers and engaging less with students. At the same time there is an increasing emphasis on efficiency, accountability and raising revenue (Alemdaroglu, 2011), sometimes preventing academics affording travel costs and conference fees (Witt, Sykes \& Dartus, 1995).

Therefore. attention needs to be devoted to creating spaces, motivations and capacities to help academics meet the demands of an increasingly pressured $\mathrm{HE}$ environment (Kahn, Goodhew, Murphy \& Walsh, 2013). This pressure is said to be greater on account of mass HE and increasing international research competitiveness, impacting on the traditional role of teaching and research academics (Clegg, 2008). Indeed, Gustavsen (2001) proposes that rich and diverse networks of professional relationships have the potential to meet the demands. Studies that have investigated academic networks have been somewhat limited in their scope. Explorations of networks for learning and teaching as well as advice-seeking about best teaching practice have mainly been conducted from a local perspective (Pataraia, Margaryan, Falconer \& Littlejohn, 2013). Fewer studies have sought to identify the processes of academic transnational networks. We suggest that it is important to differentiate between communities, groups and networks to avoid misleading and perpetuating simplistic notions of networks. Furthermore, we argue that this is important for understanding not only the impact of networks on learning and teaching, but how academics themselves justify the resources utilised for networking. 


\section{Methodology}

This paper thus far has considered the role that transnationalism, CoPs and NoPs play in our understanding of academic networking from a general higher education perspective. The empirical data from the study drew from specifically learning and teaching networks and used a mixed-methods approach that included an online survey and semi-structured interviews with 40 academics who volunteered to participate. The data was collected from academics within any Geographical discipline who participated in either one or more of the nine networks dedicated to learning and teaching to varying degrees between 2009 and 2012. The interviews, ranging from 40 minutes to an hour in duration were recorded with a dictaphone and transcribed with the data thematically analysed within NVivo software with the narratives being coded into themes and subthemes. To explore the integral social relationships an inductive methodology approach was taken in the analysis of the data (see, for example, Thorpe \& Holt, 2008).

The nine networks in the study were chosen as they were: learning and teachingcentric; geographically focussed; communicated in English and operated both online and face-to-face.

The nine networks were:

Anglo-American based

- GFDA (Geography Faculty Development Alliance)

- Giraffe (Geographical Information Research and Future-Facing Education)

- INLT (International Network for Learning and Teaching Geography in Higher Education)

- NCGE (National Council for Geographic Education)

European-based

- Eurogeo (European Association for Geographers)

- Herodot (Thematic Network for Geography in Higher Education) 


\section{Global}

- CGB (Commonwealth Geographical Bureau)

- CGGE (Centre for Global Geography Education (Internationalising the Teaching and Learning of Geography)

- IGU-CGE (International Geographical Union-Commission on Geographical Education)

They were of particular interest to study as a sub-group of all of the many networks as they specifically offered spaces, both corporeal and online for those academics interested in pedagogy. As such, the research aim was to explore the motivations, experiences and outcomes of academic networking for those with learning and teaching focus (as opposed to purely research-driven) academic pursuits. 
Table ??? Network characteristics ${ }^{1}$

\begin{tabular}{|c|c|c|c|c|c|c|c|c|c|c|}
\hline \multirow{3}{*}{ TNLT } & \multicolumn{8}{|c|}{ Logistics } & \multicolumn{2}{|c|}{ Organisers } \\
\hline & \multirow{2}{*}{ 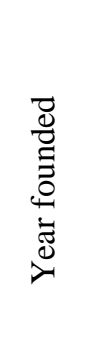 } & \multicolumn{3}{|c|}{ 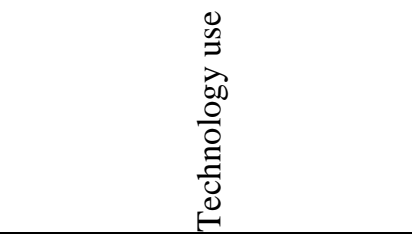 } & \multirow{2}{*}{ 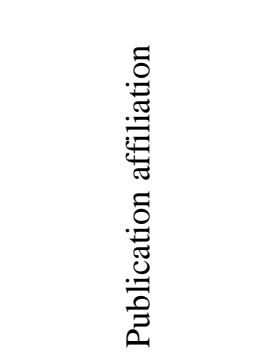 } & \multirow{2}{*}{ 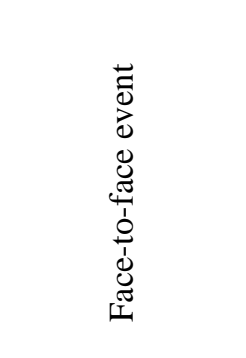 } & \multirow{2}{*}{ 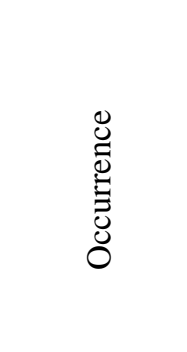 } & \multirow{2}{*}{ 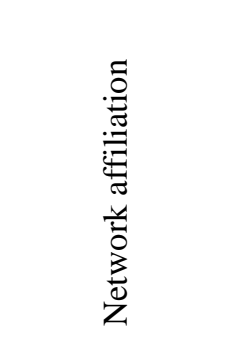 } & \multicolumn{2}{|c|}{$\begin{array}{l}\dot{\bar{D}} \\
\frac{\overrightarrow{0}}{0} \\
0\end{array}$} \\
\hline & & $\begin{array}{l}\text { Web } \\
\text { site }\end{array}$ & Email & $\mathrm{OSN}^{2}$ & & & & & $\mathrm{~F}$ & $\mathrm{M}$ \\
\hline NCGE & 1915 & $\checkmark$ & $\checkmark$ & $\checkmark$ & $\begin{array}{c}\text { Journal of } \\
\text { Geography } \\
\text { Geography } \\
\text { Teacher RIGEO }\end{array}$ & & Annually & AAG & 2 & 2 \\
\hline IGU-CGE & 1922 & $\checkmark$ & $\checkmark$ & & IRGEE $^{3}$ & $\begin{array}{c}\text { International } \\
\text { Geographical } \\
\text { Congress } \\
\end{array}$ & Annually & Eurogeo & 3 & 8 \\
\hline CGB & 1968 & $\checkmark$ & $\checkmark$ & & $\begin{array}{c}\text { Journal of Higher } \\
\text { Education in } \\
\text { Africa }\end{array}$ & $\begin{array}{c}\text { IGU } \\
\text { Own workshop }\end{array}$ & Quadrennial & $\begin{array}{l}\text { Commonwealth } \\
\text { Foundation, } \\
\text { IGU }\end{array}$ & 2 & 10 \\
\hline Eurogeo & 1979 & $\checkmark$ & $\checkmark$ & $\checkmark$ & $\begin{array}{c}\text { European Journal } \\
\text { of Geography } \\
\text { RIGEO }^{4}\end{array}$ & Own conference & Annual & Herodot & 1 & 7 \\
\hline
\end{tabular}

${ }^{1}$ Data correct as of December 2012

${ }^{2}$ Online Social Networking

${ }^{3}$ International Research in Geographical and Environmental Education

${ }^{4}$ Review of Geographical Education Online 
Table ??? Network characteristics continued

\begin{tabular}{|c|c|c|c|c|c|c|c|c|c|c|}
\hline \multirow{3}{*}{ TNLT } & \multicolumn{8}{|c|}{ Logistics } & \multicolumn{2}{|c|}{ Organisers } \\
\hline & \multirow{2}{*}{ 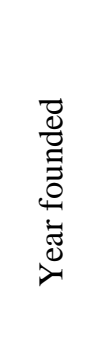 } & \multicolumn{3}{|c|}{$\begin{array}{l}0 \\
0 \\
0 \\
00 \\
0 \\
0 \\
0 \\
0 \\
0 \\
\oplus\end{array}$} & \multirow{2}{*}{ 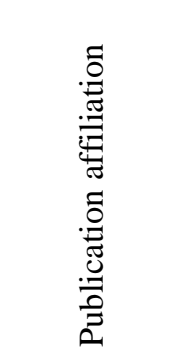 } & \multirow{2}{*}{ 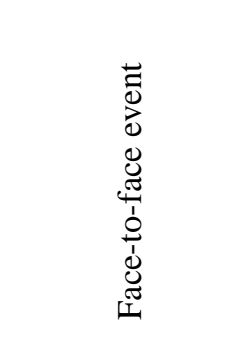 } & \multirow{2}{*}{ 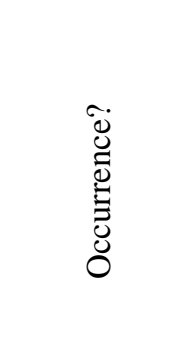 } & \multirow{2}{*}{ 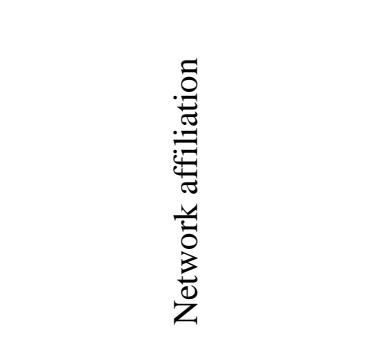 } & \multicolumn{2}{|c|}{ 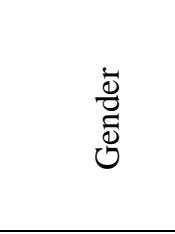 } \\
\hline & & $\begin{array}{l}\text { Web } \\
\text { site }\end{array}$ & Email & $\mathrm{OSN}^{5}$ & & & & & $\mathrm{~F}$ & M \\
\hline INLT & 1999 & $\checkmark$ & $\checkmark$ & & JGHE & $\begin{array}{c}\text { AAG } \\
\text { IGU } \\
\text { Own workshop }\end{array}$ & Bi-annually & AAG & 1 & 2 \\
\hline Herodot & 2002 & $\checkmark$ & $\checkmark$ & $\checkmark$ & Own books & Own conference & Annually & $\begin{array}{c}\text { European Commission } \\
\text { IGU } \\
\text { Eurogeo } \\
\end{array}$ & 1 & 1 \\
\hline GFDA & 2002 & $\checkmark$ & $\checkmark$ & $\checkmark$ & & Own workshop & Annual & $\begin{array}{c}\text { Canadian Association of } \\
\text { Geographers, } \\
\text { AAG }\end{array}$ & 0 & 2 \\
\hline CGGE & 2003 & $\checkmark$ & $\checkmark$ & & $\begin{array}{c}\text { IGU-CGE } \\
\text { INLT } \\
\text { NCGE } \\
\text { NSF }^{6} \\
\end{array}$ & Own workshop & $\begin{array}{c}\text { Annual } \\
\text { Bi-annually }\end{array}$ & $\mathrm{AAG}$ & 0 & 3 \\
\hline Giraffe & 2009 & $\checkmark$ & & & & & & $\begin{array}{l}\text { Commonwealth } \\
\text { Foundation, } \\
\text { IGU }\end{array}$ & 1 & 1 \\
\hline
\end{tabular}

${ }_{6}^{5}$ Online Social Networking

${ }^{6}$ National Science Foundation 
This paper draws on the interviews with the 40 academics who attended face-toface meetings organised through their networks and/or subscribed to the network email listserv. No distinction between levels of activity was made apart from organiser and participant although as invitations to be interviewed were distributed by network listservs, it can be assumed that all of the interviewees participated in listservs but not all had participated in a face-to-face activity. The interviewees worked within a geographical discipline at a HE institution and all of the participants spoke English as a native or second language.

Face-to-face interviews (37\%) and Skype interviews (63\%) were split between the UK (28\%) at the academics' home UK HE institution and the USA (72\%) at the 2010 AAG (Association of American Geographers) Annual Conference, Seattle.

\section{Interviewee characteristics}

Interviewees were employed at HE institutions within Europe (50\%), North America (35\%), Australasia (10\%), Asia (3\%) and Africa (3\%). ${ }^{7}$ All of the nine networks were represented by at least one interviewer with an organiser of that network with interviewees often organising in some capacity and/or participating in one or more network. These academic are what we may call today 'boundary-spanners' as they are individuals who feature in various positions within different societies and networks, continually influencing and bringing their personal knowledge and contacts with them (Donert, 2011). Power was an important aspect of this study as the tensions of student / academic and organiser / participant had to be negotiated between the researcher and the

\footnotetext{
${ }^{7}$ Of which the UK makes up $38 \%$
} 
respondent. Ethical considerations such as anonymity of network organisers and participant were taken into account by deleting all identifying markers and anonymity was taken into account during dissemination of findings (Israel \& Hay, 2006). Therefore it is not appropriate to attribute gender and the label of organiser to the interviewees by their individual networks as academics may be identifiable by these characteristics.

Table 1: Interview type and gender of interviewee

\begin{tabular}{|l|cc|cc|cc|c|c|}
\hline & \multicolumn{3}{|c|}{ Interview type } & \multicolumn{3}{c|}{ Gender } \\
\hline & \multicolumn{2}{|c|}{ Face-to- } & \multicolumn{2}{c|}{ Online } & \multicolumn{2}{c|}{ Female } & \multicolumn{2}{c|}{ Male } \\
& \multicolumn{2}{|c|}{ face } & & & & & & \\
\cline { 2 - 10 } & $\mathrm{n}$ & $\%$ & $\mathrm{n}$ & $\%$ & $\mathrm{n}$ & $\%$ & $\mathrm{n}$ & $\%$ \\
\hline Organiser & 8 & 20 & 5 & 13 & 2 & 5 & 11 & 28 \\
\hline Participant & 7 & 17 & 20 & 50 & 15 & 37 & 12 & 30 \\
\hline Total & 15 & $\mathbf{3 7}$ & 25 & $\mathbf{6 3}$ & 17 & $\mathbf{4 2}$ & 23 & $\mathbf{5 8}$ \\
\hline
\end{tabular}

Source: Interview data

Figure ???: Geographical locations of all interview respondents

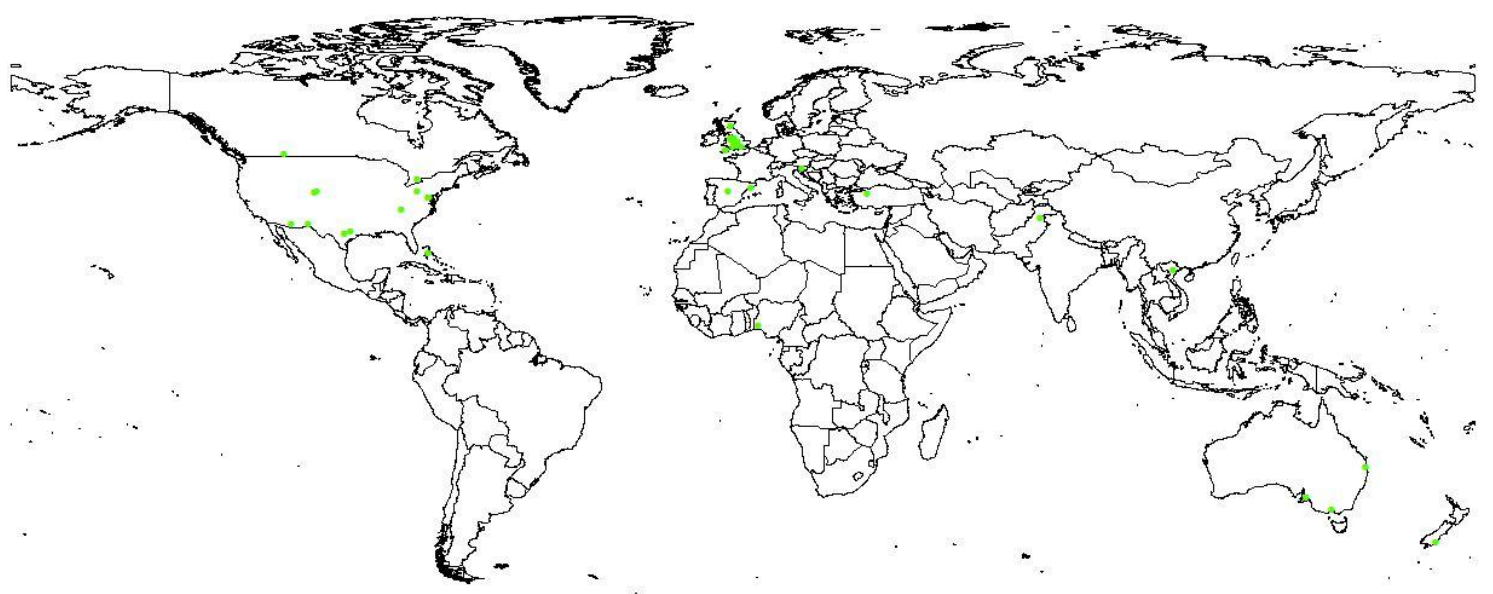

Figure ???: Geographical locations of UK interview respondents 


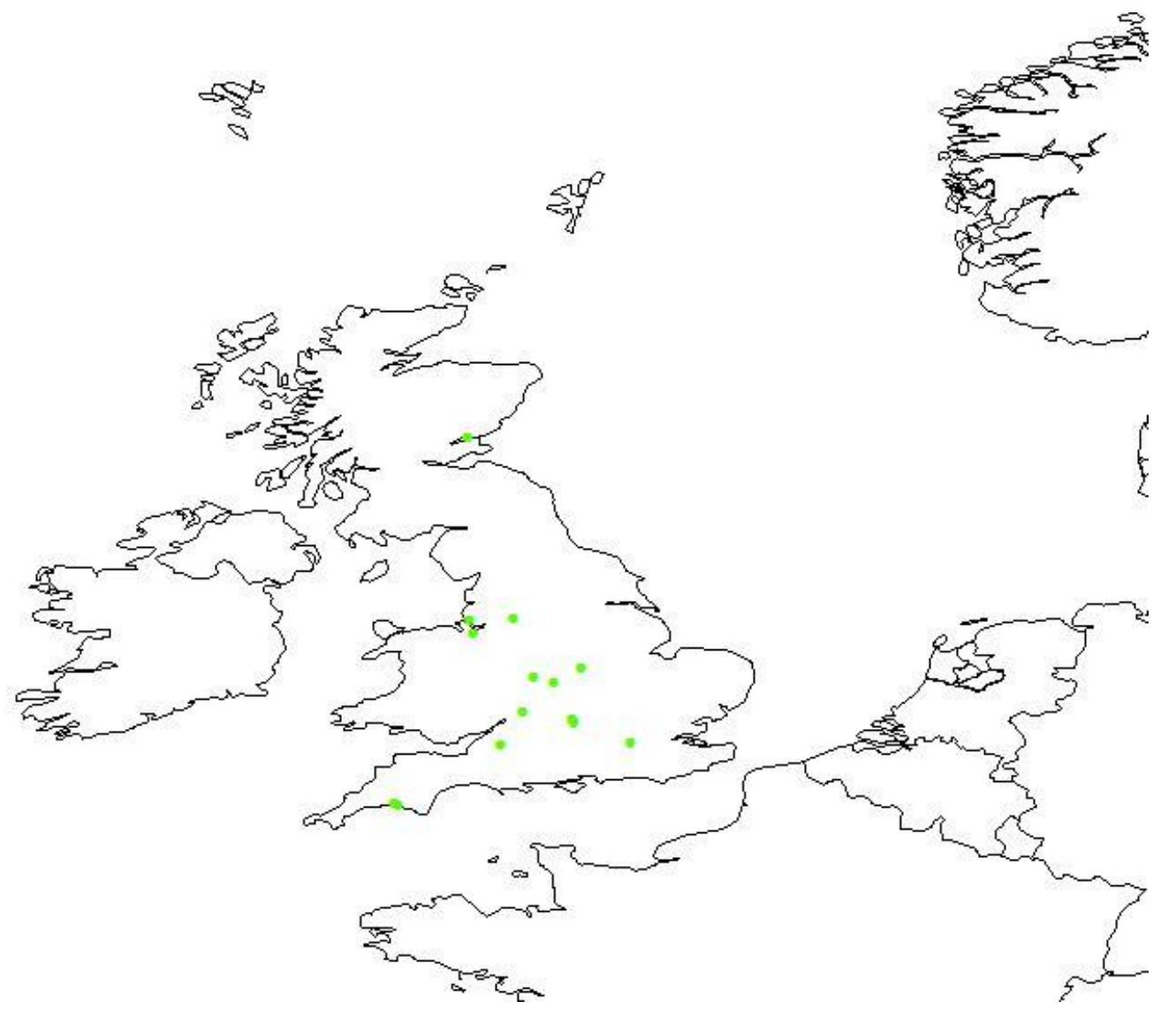

Due to the nature of the geographical distribution of the interviewees and the network bases, we argue that the experience of the academics is a transnational one. As one example, one of the interviewees was an academic, born in a South American country, but living at the time of the interview in North America spoke English as a second language. This academic was an organiser of a global network and was a participant in two other Anglo-American based networks. This academic was interviewed during attendance at a face-to-face event in the USA. Drawing upon the network society concept, we argue that transnational is the most appropriate description for the networks as often the networks are run by one or two people from one institution and if that person retires or passes responsibility to others, the network's physical and virtual 'place' can change continent overnight. The networks are not between or within 
nation states or borders, often being shared across continents, therefore global or national do not justify the space that the networks operate over.

\section{Findings}

From the analysis, three main themes emerged around motivations for engagement, experiences of involvement and outcomes of participation. Despite presenting the three themes separately here, the research findings suggest that they are by no means mutually exclusive. For example, academics' motivations for networking such as collaborative publication or career promotion opportunities were often reflected in the outcomes.

Common sub-themes of tangibility and intangibility emerged from the many narratives around motivations, experiences and outcomes. Figure 2 shows how the relationships between the themes and sub-themes require a different level of explanation than that of CoP or NoP. In blue are the motivations, experiences and outcomes, whilst in red are the intangible factors and in green are the tangible factors that will be discussed. We draw upon the concept of 'networked individualism' which describes the looser and more fragmented networks within which academics operate, a conceptualisation more complex than the $\mathrm{CoP}$ or NoP literature suggests. 
Figure ???: Motivations, experiences and outcomes of academic networking

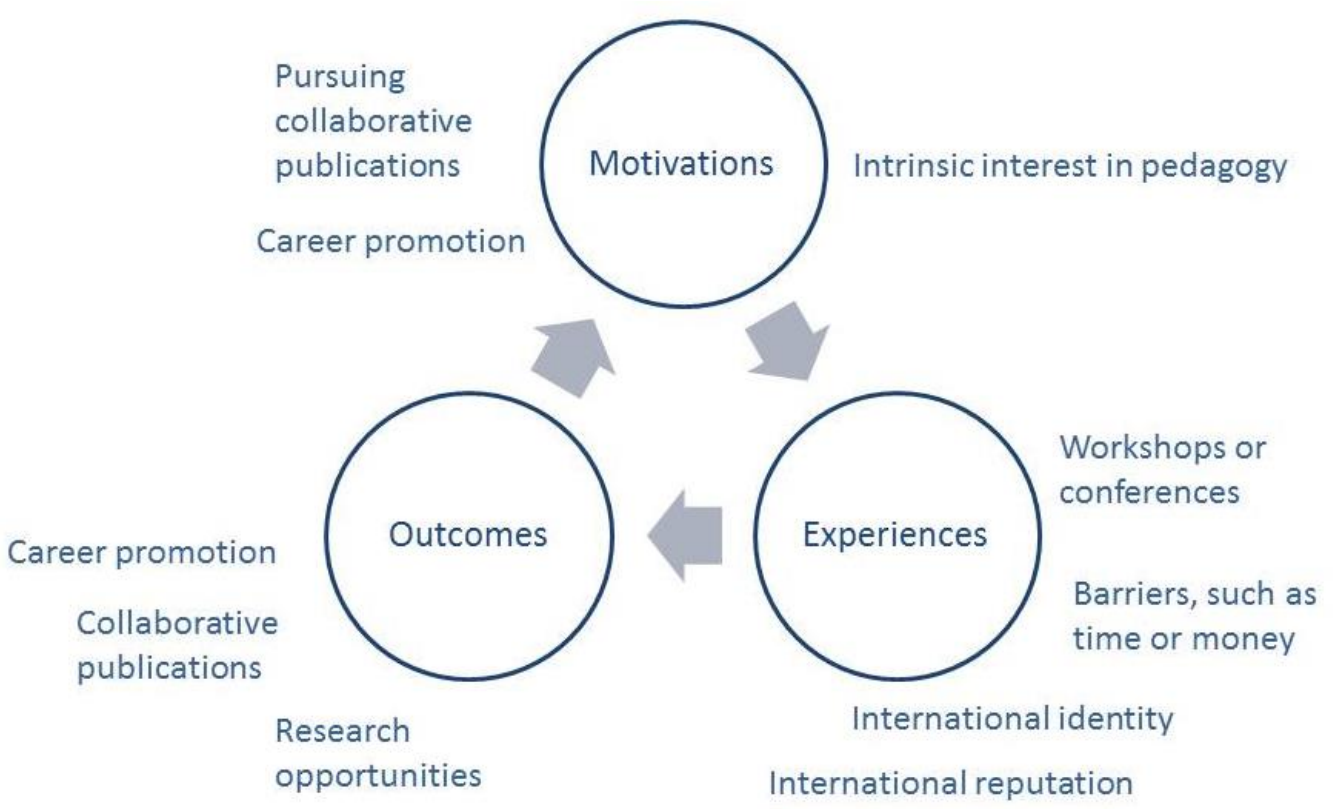

\section{Motivations to network}

There were multiple reasons academics chose to participate in a TNN with three main motivations emerging. These were:

1. an intrinsic interest in pedagogy

2. pursuing collaborative publication

3. career promotion

The first of these motivations is perhaps unsurprising. Enjoyment in teaching and a passion for learning were revealed to be fundamental to many of the academics' motivations. Included in this is the role of the multiple intangible aspects of teaching, 
and how important they can be for motivating academics to go beyond their university to find like-minded people to share and collaborate with. The academics did not appear to be networking for the benefit of their Department or School (although this may have been an indirect consequence), but networking for personal interest, curiosity and care for student learning. Moreover, unlike locally-bound CoP (Amin \& Roberts, 2004) these academics were engaging in networks with peers who were spatially and geographically distributed.

Some of the TNNs in the study offered a collaborative writing space thus presenting academics with an opportunity to write a peer-reviewed article in an international journal. As Turner, Brown and Edwards-Jones (2013) report, such opportunities can have a positive impact on confidence and self-belief in their ability to write. However, there is another perspective of publishing that highlights the preoccupation with academic self-interest. For example it is argued that, 'quantity of publications is the keynote, as this accrues wealth for the university and the researcher (this being the cornerstone of corporate thinking' (Weinberg \& Graham-Smith, 2012, p. 74). In other words, networking for this purpose is masking individualism. It also fits with the idea of networked individualism highlighting how people fashion complex identities according to the requirements of work and lifestyle (Rainie \& Wellman, 2012). This point was particularly well demonstrated by a participant who stated that they were attracted to this kind of opportunity stating:

The fact that you wrote a publication collaboratively internationally as a team. That sounded brilliant and it looked like you would go to it, network with lots of people and get a publication (I18) 
Getting published is closely linked to career progression more broadly. International peers can contribute to the enhancement of one's career progression by, for example, providing references for professorship. The professor's profession is a topic recognised as an area of academia that has been corporatised and has 'lost its public voice and commitment as well as its distinctiveness' (Weinberg \& GrahamSmith, 2012, p. 79). Yet for the participants in this study, networks offered opportunity to pursue their ambition. As the same participant explained:

For my own selfish career development, was I guess the main motivation in that thinking. At [university] there are different routes to professor and I'm a principal lecturer at the top of my scale and so the next obvious move for me is to move to professor (I18)

As this shows, despite the pressures of academia, these individuals were creating space to exercise their personal autonomy and agency (Clegg, 2008). Another participant focused more on the genuine pursuit of knowledge about education in other countries in order to compare teaching and learning:

I wanted to be more international, I wanted to compare the other countries in geographical education all over the world, I want to solve this problem, to listen and to talk. I wish to be more international and wish to be more active (I37)

As these quotes highlight, there was often a strategic nature to some of the academics' motivations to participate in networking, above and beyond their day jobs and responsibilities. Indeed, they perhaps reflect the increasing demands of the HE 
environment as described by Kahn et al (2013), Clegg (2008) and Gustavsen (2001). However, there was also evidence of a mixture of collaborative and more egocentric motivations for engaging in networks. This might be explained by Chua (2013) who emphasises the importance of context when considering networked individualism and recognises that different kinds of role relationships can be mobilised for different kinds of tasks. In an effort to meet the needs of sometimes conflicting demands, these participants appeared to be seeking opportunities to address several different needs at once. Arguably it was for this end that looser and more fragmented networks were preferred.

\section{Experiences of networking}

There were three main factors that permeated the experiences of participating in the TNNs:

1. International identity or reputation (online or face-to-face)

2. Workshops or conferences

3. Barriers such as time and money

An international reputation was presented as central to academic activities in a period of growing inter-cultural awareness and communication across borders, as well as increasing internationally focussed curricula. Alongside increasing international student mobility (see, for example, Findlay, King, Stam \& Ruiz-Gelices, 2005 and King, 2010) and circular academic mobility from and to the UK (Jöns, 2009; 2011) there was perceived to be a complex narrative that encouraged academics to seek internationalised exchanges of knowledge. 
My international experience has clearly broadened my awareness, things going on in the world and being open to different approaches (I16)

Face-to-face communication at events such as workshops or conferences was considered a critical aspect of the networking experience. The availability of face-toface meetings provided short and irregular windows of opportunity for physical copresence. The formal spaces of the keynote address or organised sessions were often blurred with the informal spaces of coffee breaks and socialising at conference dinners as the following extract reveals:

Socialising, I think it's just vital, it's a vital part, I think what happens is that if you're looking to, using the network as a mechanism to help underpin collaborative research, co-authoring and the like, to some degree you can collaborate with people who you don't know. I think so much of this collaborative work very often depends on having a working relationship with someone who you can work out whether or not that relationship will work. (I29)

Despite the drivers and benefits of conference attendance, it must be noted that face-to-face meetings are opportunities only for those participants that have the desire and of course, money and time to travel. International conference attendance is achieved by having three economic variables; income, travel cost and conference fee (Witt, Sykes \& Dartus, 1995). Academics that faced these barriers and could neither afford to travel to network viewed the use of online networking as vital for sustaining a constant line of communication with other academics globally. There were also discrepancies between Department and Faculty contributions to their networking 
activities ranging from no contribution at all to full-funding. Many academics selffunded their attendance at international events to ensure that they had opportunities to build and maintain an international reputation.

The network meeting comes out of my pocket, like the educational conference I've just got back from, that came out of my pocket, which is why I have a real hard time trying to make international meetings, I should probably go to international meetings, I just don't have the money. (I19)

Interestingly, the greater the international reputation, the more opportunities for funding were available to that person.

Quite often it's by invitation, you get to a certain stage in life and they want you on board... so they'll pay. I've travelled quite widely on that. (I24)

For some academics, their networking activities were perceived by colleagues as detrimental to the Department or Faculty and perhaps points to unequal access to learning at work (Hodkinson and Hodkinson, 2005). However, as the following quote shows, it was also a matter of prioritising and balancing teaching and networking:

A few colleagues think that, comment on the fact that I spend too much of my time networking. I've always argued that, that level of networking is like maybe [conference] for a few days, [conference], what about this, them two days, I always thought that was part of the activities. I've always managed to balance teaching 
demands against the network demands. I suppose eventually when the funding dips away, the conferences and networking will shrink as well. (I21)

Time is an aspect of HE that has received some attention in the past. For example, Clegg (2010, p. 360) has argued that there has been an increasing tempo of university life and that we need to be able to challenge the 'emptied-out timeframe of the present future' for harnessing knowledge. Indeed, Weinberg and Graham-Smith (2012) claimed that as a result of the advent of corporatisation in the modern era, time is an assessor rather than a manifestation of intelligent work. The extract above suggests not only an awareness of this assessment but also demonstrates a conscious determination to meet demands of both networking and teaching.

\section{Outcomes of networking}

The effects of participating in a transnational network both personally and professionally were discussed mostly in relation to individual outcomes, both in terms of tangibility and intangibility. A framework such as Millen et al's (2002) value system aids an understanding of the principles of tangibility and intangibility to highlight how academic motivations and outcomes of networking are mirrored. So, for example, the three major tangible themes that ran through the narratives of outcomes are:

1. Collaborative publication

2. Career promotion

3. Research opportunities

Tangible outcomes included co-written publications and career promotion activities alongside new avenues of research collaborations and writing opportunities. 
As one can see, collaboration and promotion are mentioned in these outcomes of networking, similar to the motivations to network, discussed previously. The outcomes of network participation in general however were more valued when there was a tangible output such as a publication or promotion possibility:

Publications are like that parable. The chicken who baked the bread and no one was willing to be involved until the end, then they're all hanging around because they wanted to eat some of it. (I29)

There was therefore an issue of trust when writing publications among those in the network and the sense of value in the outcome rather than the process of publication. The value of publications was also discussed in relation to more senior managers of academics, perhaps a result of the 'managerialist ideology' that Kolsaker (2008) has explored:

I think that they can see the value to a certain extent particularly when it becomes tangible in the form of articles, I think that's when they really do tend to recognise the benefits. (I31)

Intangible outcomes were also described by the network participants in terms of professionalising the discipline through recognition, value and sharing knowledge as well as personal connections such as friendship and new social circles. Dewsbury and Naylor (2002) argue that acts of dissemination are the goalposts of networking as they enable the interchange of agendas and arguments and so bring knowledge back to one's department with sharing learning and teaching considered to be a professional outcome. 
Such beneficial professional outcomes are similar to Millen et al's (2002) categorisation of CoP engagement as ‘community' outcomes. Individualism and collectivism manifest in motivations to network and therefore it should be no surprise that the outcomes of participation are seen in this way too. Wayne et al (1997) suggest that knowledgesharing could be included within discussions of good citizenship where network participants are buoyed by support and reciprocate by engaging more readily. The knowledge that flows between communities and networks have yet to be explored fully (Tagliaventi \& Mattarelli, 2006). However the data presented here underlines how networks such as TNNs, where participants are geographically dispersed, can lead to outcomes that act as leverage for participants to maintain their personal HE networks. Overwhelmingly, the outcomes for academics were beneficial. Yet it can be argued that they were mostly individualistic, with few benefits appearing to extend to others. Networks therefore play an important role in the direct and catalytic effect on outcomes. However, as Schlager and Frasco (2003, p. 206) point out the question of what catalyses positive outcomes from networks and CoP remains largely unresolved.

\section{Conclusion}

The research findings presented here highlight that although the networks examined for this paper have similar traits to $\mathrm{CoP}$ and NoP, they are in fact different and distinct to these variations in networks. Academic networking manifests itself in ways that are at various levels of tangibility. Whilst the exact 'mix' of tangibility could vary according to individual the existence of these features were common to all. We argue that a more accurate conceptualisation for the networks would be to refer to them as Transnational Networks or TNNs. In doing so we concur with $\mathrm{Ng}$ and Pemberton 
(2013) that there is a need to explore issues relating to size, longevity and membership which will add to ongoing CoP debates.

Emerging from the data was a strong sense that the motivations for engaging in teaching and learning networks were individual but that a tension exists for academics when justifying this. Justifications included spending time on networking away from university rather than teaching on campus or participating in administrative duties. The academics who identified or participated in the networks arguably fit within the 'tribe' concept (Becher, 1989) of belonging to a particular area of higher education and associating oneself with other like-minded academics.

We suggest that the reasons for this could relate to the wider context of the HE environment and networked individualism. In this vein we agree with Chua (2013, p. 622) that we have, 'a situation of autonomous individuals matching roles to tasks in ways they see fit'. Indeed, there is a need to position networked individualism in context. Academic transnational networks are expanding and extending in an era of increasing accountability within universities and global socio-economic pressure. This change is tied to a greater demand for university education and an increasing emphasis on efficiency, accountability and raising revenue (Alemdaroglu, 2011) and in a wider context, greater public accountability from professional bodies including higher education (Brennan, King \& Lebeau, 2004).

We argue that despite intentions of sharing and engaging in reciprocal knowledge exchange, the term 'network' is just as vague as 'community' (Cox, 2007). However, it does not suggest that the networks described here are unfriendly or inharmonious (Fox, 2000). We also argue that despite 'networked individualism' and 'advantage-seeking' not being a new phenomenon within the networks we focused on, these characteristics and traits are intensified. Thus, the pressures of working in a HE 
environment drive altruistic behaviour. This has occurred through the wider developments that this paper has discussed such as an increasingly globalised higher education system and multiple combinations of offline and online activities to satisfy the seemingly ever-growing body of work an academic needs to produce.

Acknowledgements: The authors would like to thank Professor Jürgen Enders especially for his insightful comments on this paper and to all others who read and commented on the drafts.

\section{References}

Alemdaroglu, A. (2011) Selling Futures Across Borders: The Global Trade of Higher Education and 'For-profitization' in Turkey. Anthropology Brown Bag Series, Stanford University, USA. Retrieved March 2014 from https://www.academia.edu/2131458/Selling_Futures_across_Borders_The_Global_Trad e_of_Higher_Education_and_For-profitization_in_Turkey

Amin, A. \& Roberts, J. (2004). Knowing in action: Beyond communities of practice. Research Policy, 37, 353-369.

Ardichvili, A., Page, V. \& Wentling, T. (2003). Motivation and Barriers to Participation in Virtual Knowledge-sharing Communities of Practice. Journal of Knowledge Management, 7(1), 64-77.

Bath, D. \& Smith, C. (2004). Academic Developers: An Academic Tribe Claiming their Territory in Higher Education. International Journal for Academic Development, 9(1), 9-27.

Becher, T. (1989). Academic tribes and territories: Intellectual inquiry and the cultures of disciplines. Milton Keynes, England: Society for Research into Higher Education and The Open University Press.

Bhandari, R. \& Blumenthal, P. (2008). The Europa World of Learning. London: Routledge. 
Boland, R.J., \& Tenkasi, R.V. (1995). Perspective making and perspective taking in communities of knowing. Organisation Science 6(4), 350-372.

Bowen, H., Schuster, J. (1986). American professors: A national resource imperiled. New York: Oxford University Press.

Brennan, J., King, R. \& Lebeau, Y. (2004). The Role of Universities in the Transformation of Societies. An International Research Project Synthesis Report Centre for Higher Education Research and Information. Retrieved March 2014 from http://www.open.ac.uk/cheri/documents/transf-final-report.pdf

Brown, J. S. \& Duguid, P. (2000). The Social Life of Information (2nd ed.). Boston: Harvard Business School.

Buchbinder, H. \& Newson, J. (1985). 'The academic work process, the professoriate and unionization'. In C. Watson (Ed.), The professoriate - occupation in crisis. Toronto: Higher Education Group, Ontario Institute for Studies in Education.

Castells, M. (1996, 1998) The Rise of the Network Society, Volume 1 The Information Age: Economy, Society and Culture. Blackwell, Oxford.

Castells, M. (2001) The Internet Galaxy. Oxford University Press, Oxford.

Castells, M. (2004) (ed) The Network Society: A Cross Cultural Perspective. Edward Elgar Publishing Limited, Cheltenham.

Castells, M. (2009) Communication Power. Oxford University Press, Oxford.

Chua, V. (2013). Contextualising 'networked individualism': the interplay of social categories, role relationships and tasks. Current Sociology 6(5-6), 602-625.

Clegg, S. (2008). Academic identities under threat? British Educational Research Journal 34(3), 329-45.

Clegg, S. (2010). Time Future - the dominant discourse of higher education. Time and Society 19(3), 345-364. 
Cox, A. M. (2007) Beyond information: factors in participation in networks of practice, a case study of web management in UK Higher Education. Journal of Documentation, 63(5), 765-787

Dewsbury, J. \& Naylor, S. (2002). Practising geographical knowledge: fields, bodies and dissemination, AREA 34(3), 253-260.

Dubé, L., Bourhis, A. \& Jacob, R. (2006). Towards a Typology of Virtual Communities of Practice. Interdisciplinary Journal of Information, Knowledge, and Management, 1, 69-93.

Engeström, Y. (2001). Expansive Learning at Work: Toward an activity theoretical Reconceptualization. Journal of Education and Work, 14(1), 133-156.

Etzioni, A. (1988). The Moral Dimension. London: Free Press.

Faraj, S. \& Wasko, M. (2001). The web of knowledge: An investigation of knowledge exchange in networks of practice. Retrieved March 2014 from http://flosshub.org/20

Findlay, A., King, R., Stam, A. \& Ruiz-Gelices, E. (2005). International Opportunities: Searching for the Meaning of Student Migration, Geographica Helvetica, 60(3), 192200.

Fox, S. (2000). Communities of Practice, Foucault and Actor-Network Theory. Journal of Management Studies 37(6), 853-868.

Glaser, B. G. \& Strauss, A. (1967). The Discovery of Grounded Theory: Strategies for Qualitative Research. London: Aldine Transaction.

Gustavsen, B. (2001). Theory and practice: the mediating discourse. In P. Reason \& H. Bradbury (Eds), Handbook of Action Research: the concise paperback edition (17-26). Thousand Oaks, CA: Sage.

Hager, P. \& Hodkinson, P. (2009). Moving beyond the metaphor of transfer of learning, British Educational Research Journal, 35(4), 619-638.

Hodkinson, H. \& Hodkinson, P. (2005). Improving school teachers' workplace learning, Research Papers in Education, 20(2), 109-131. 
Holloway S L, O’Hara S L, Pimlott-Wilson H, 2012, "Educational mobility and the gendered geography of cultural capital: the case of international student flows between Central Asia and the UK" Environment and Planning A 44(9) 2278 - 2294

Israel, M. \& Hay, I. (2006) Research Ethics for Social Scientists. London: Sage Publications, Ltd.

Johnson, P. (2008). INDUCTIVE ANALYSIS. In R. Thorpe, \& R. Holt (Eds.), The SAGE Dictionary of Qualitative Management Research. (pp. 113-116). London, United Kingdom: SAGE Publications Ltd. doi: http://dx.doi.org/10.4135/9780857020109.n52

Kahn, P., Goodhew, P., Murphy, M. \& Walsh, L. (2013). The scholarship of teaching and learning as collaborative working: a case study in shared practice and collective purpose. Higher Education Research \& Development, 32(6), 901-914.

Kim, T. (2008). Transnational academic mobility in a global knowledge economy. In D. Epstein, R. Boden, R. Deem, F. Rizvi \& S. Wright (Eds.). The World Yearbook of Education 2008: Geographies of knowledge and geometries of power: Framing the future of higher education (pp. 319-337). London: Routledge.

Kim, T. (2010). Transnational academic mobility, knowledge, and identity capital. Discourse: Studies in the Cultural Politics of Education, 31(5), 577-591.

Kligyte, G. \& Barrie, S. (2014). Collegiality: leading us into fantasy - the paradox resilience of collegiality in academic leadership. Higher Education Research \& Development 33(1), 157-169.

Kolsaker, A. (2008). Academic professionalism in the managerialist era: a study of English universities. Studies in Higher Education, 33(5), 513-525.

Jöns, H. (2009). 'Brain circulation' and transnational knowledge networks: studying long-term effects of academic mobility to Germany, 1954-2000, Global Networks, 9(3), 315-338.

Jöns, H. (2011). Transnational Academic Mobility and Gender. Globalisation, Societies and Education, 9(2), 183-209. 
Larsen, J., Axhausen, K. \& Urry, J. (2006). Geographies of Social Networks: Meetings, Travel and Communications. Mobilities, 1(2), 261-283.

Latour, B. (2005). Reassembling the Social: An Introduction to Actor-Network-Theory. Oxford: Oxford University Press.

Lave, J. \& Wenger, E. (1991) Situated Learning: legitimate peripheral participation. Cambridge: Cambridge University Press.

Maringe, F. \& Foskett, N. (Eds). (2010). Globalisation and Internationalisation in Higher Education: theoretical, strategic and management perspectives. London: Continuum.

McCormick, R., Carmichael, P., Fox, A. \& Procter, R. (2010). Researching and Understanding Educational Networks. London: Taylor \& Francis.

Mellor, J., Ingram, N., Abrahams, J. \& Beedel, P. (2014). Class matters in the interview setting? Positionality, situatedness and class. British Educational Research Journal 40(1), 135-149.

Millen, D. R., Fontaine, M. \& Muller, M. (2002). Understanding the Benefits and Costs of Communities of Practice. Communications of the ACM, 45(4). Retrieved March 2014 from

http://portal.acm.org/citation.cfm?id=505276\&coll=portal \&dl=ACM\&CFID=2233583 $\underline{\& C F T O K E N=49128487}$

Ng, L. \& Pemberton, J. (2013). Research-based communities of practice in UK higher education, Studies in Higher Education, 38(10), 1522-1539.

Nickols, F. (2003). Communities of Practice What's It Like Inside? Retrieved March 2014 from http://home.att.net/ nickols/articles.htm

Pataraia, N., Margaryan, A., Falconer, I. \& Littlejohn. A. (2013). How and what do academics learn through their personal networks? Journal of Further and Higher Education. Retrieved March 2014 from http://www.tandfonline.com/doi/pdf/10.1080/0309877X.2013.831041 
Putnam, R. D. (2000) Bowling Alone: The Collapse and Revival of American Community. Simon and Schuster, New York.

Rainie, L. \& Wellman, B. (2012). Networked: the new social operating system. Massachusetts, USA: MIT Press.

Rainbird, H., Munro, A. \& Holly, L. (2004). The Employment Relationship and Workplace

Learning. In H. Rainbird, A. Fuller and A. Munro (Eds). Workplace Learning in Context, (pp. 38-54) London: Routledge.

Sassen, S. (2000) Cities in a World Economy, (2nd ed). Pine Forge Press, London. Sassen, S. (2002) Global Networks, Linked Cities. Routledge, New York.

Schlager, M. S. \& Fusco, J. (2003) Teacher Professional Development, Technology and Communities of Practice: Are we putting the cart before the horse? The Information Society, 19, 203-220.Scott, J. (2011). Conceptualising the Social World. Principles of Sociological Analysis. Cambridge: Cambridge University Press.

Stewart, D. (2003). Status Mobility and Status Stability in a Community of Free Software Developers. Academy of Management Proceedings. Retrieved March 2014 from http://connection.ebscohost.com/c/proceedings/13792424/status-mobility-status$\underline{\text { stability-community-free-software-developers }}$

Swan, J., Newell, S. \& Robertson, M. (1999). Central agencies in the diffusion and design of technology: a comparison of the UK and Sweden. Organization Studies, 20(6), 905-931.

Tagliaventi, M. R. \& Mattarelli, E. (2006). The role of networks of practice, value sharing and operational proximity in knowledge flows between professional groups. Human Relations, 59, pp. 291-319.

Thompson, M. (2005). Structural and epistemic parameters in communities of practice. Organisation Science 16(2), 151-64. 
Turner, R., Brown, T. \& Edwards-Jones, A. (2013). Writing my first academic article feels like dancing around naked: research development for higher education lecturers working in further education colleges. International Journal for Academic Development. Retrieved March 2014

http://www.tandfonline.com/doi/pdf/10.1080/1360144X.2013.792729

Vähäsantanen, K. \& Saarinen, J. (2012). The power dance in the research interview: manifesting power and powerlessness. Qualitative Research. Available at http://qrj.sagepub.com/content/early/2012/08/10/1468794112451036.abstract

Wasko, M. M., Faraj, S. \& Teigland, R. (2004). Collective Action and Knowledge Contribution in Electronic Networks of Practice. Journal of the Association for Information Systems, 5(11-12), 493-513.

Wayne, S., Shore, L. \& Liden, R. (1997). Perceived organisational support and leader member exchange: a social exchange perspective. The Academy of Management Journal, 40(1), 82-111.

Weinberg, A. \& Graham-Smith, G. (2012). Collegiality: can it survive the corporate university? Social Dynamics: A Journal of African Studies, 38(1), 68-86.

Wenger, E. (2006) Communities of Practice. Retrieved March 2014 from http://www.ewenger.com/theory/

Wenger (2008) Communities of Practice: Learning, Meaning, and Identity

Wenger, E., McDermott, R. \& Snyder, W.M. (2002). Cultivating communities of practice: A guide to managing knowledge. Boston, MA: Harvard Business School Press.

Whelan, E. (2007). Exploring knowledge exchange in electronic networks of practice. Journal of Information Technology, 22, 5-12.

Winchester, H. P. M. (1996) Ethical issues in interviewing as a research method in human geography. Australian Geographer, 27(1), 117-131. 
Witt, S. F., Sykes, A. M. \& Dartus, M. (1995) Forecasting International Conference Attendance. Tourism Management, 16(8), 559-570. 